\title{
Water use of different weed species using lysimeter and NDVI
}

\author{
Thiago F. Rodrigues ${ }^{\mathrm{a}} \odot$, Fernando F. da Cunha ${ }^{\mathrm{a}} \oplus$, Gustavo H. da Silva ${ }^{a} \oplus$, Saulo B. Condéa ${ }^{\oplus}$, Francisco C. dos S. Silva ${ }^{\mathrm{b}} \odot$ \\ a Universidade Federal de Viçosa, Viçosa, MG, Brazil. ' Universidade Estadual do Maranhão, Balsas, MA, Brazil.
}

Abstract: Background: Weeds reduce water use efficiency in crops due to water used by the weed and to the reduction in crop yield. In addition to the usual presence of weeds in the interrow of different crops, the management of these plants has moved away from the idea of total control. Thus, the amount of water lost through the evapotranspiration of weeds $\left(\mathrm{ET}_{\mathrm{W}}\right)$ must be understood.

Objective: Determine the water use and crop coefficient $(\mathrm{Kc})$ of the weed species Commelina diffusa, Cyperus rotundus, and Cynodon dactylon using drainage lysimeters associate with the Normalized Difference Vegetation Index (NDVI).

Methods: The experiment was carried out at the Lysimetric Station of the Federal University of Viçosa, in Viçosa-MG, in a randomized block design, with four treatments and four replicates. Reference evapotranspiration
(ETo), necessary to calculate Kc, was obtained in situ through lysimeters cultivated with Paspalum notatum.

Results: The highest Kc values were found in the final third of the experimental cycle, equal to $1.32,0.93$, and 0.90 for C. diffusa, C. rotundus, and $C$. dactylon, respectively. The NDVI showed a good correlation with Kc and biomass, with $\mathrm{R}^{2}$ ranging from 30.9 to $54.6 \%$ and from 46.1 to $63.1 \%$, respectively. Accumulated $\mathrm{ET}_{\mathrm{W}}$ values ranged from 336 to $473 \mathrm{~mm}$, with C. diffusa showing the highest water consumption, followed by $C$. rotundus and C. dactylon.

Conclusions: $C$. diffusa has higher $\mathrm{Kc}$ and water consumption than $C$. rotundus and C. dactylon. NDVI can be used in the estimation of the Kc and biomass of weeds.

Keywords: Crop coefficient - Kc; ETo; Evapotranspiration; Drainage lysimeter; Vegetation index

Journal Information: ISSN - 2675-9462

Website: http://awsjournal.org

Journal of the Brazilian Weed Science Society

How to cite: Rodrigues TF, Cunha FF, Silva GH, Condé SB, Silva FCS. Water use of different weed species using lysimeter and NDVI. Adv Weed Sci. 2021;39:e021233767. https://doi.org/10.51694/AdvWeedSci/2021;39:00004

Approved by:

Editor in Chief:

Carlos Eduardo Schaedler

Conflict of interest: The authors declare no conflict of interest regarding the publication of this manuscript.

Received: June 14, 2019

Approved: August 10, 2020

* Corresponding author: <fernando.cunha@ufv.br>

\section{(c) (4)}

This is an open-access article distributed under the terms of the

Creative Commons Attribution License, which permits unrestricted use, distribution, and reproduction in any medium, provided that the original author and source are credited.

Copyright: 2021

\section{Introduction}

Weeds compete with agronomic crops for water, light, and nutrients, significantly affecting agricultural yields (Fialho et al., 2012; Swanton et al., 2015). According to Cirujeda et al. (2012), the infestation of Cyperus rotundus in tomato plantation was responsible for a $64 \%$ reduction in yield compared to the area without interference from this weed. Besides the competition for resources, weeds can cause other types of damage, such as the damage to mechanized harvesting, allelopathic effects, pest and disease hosting, changes in the secondary metabolism of crops, among others (Rockenbach et al., 2018). Given this scenario, it is evident that a greater understanding of the interactions between crops and weeds is of fundamental importance for developing more efficient and sustainable agriculture.

Among the various existing species of weeds, Cyperus rotundus, Commelina diffusa, and Cynodon dactylon stand out because they are difficult to control and have an intense competition and dissemination capacity. According to Das (2008), Cyperus rotundus is present in the world's tropical and subtropical regions, interfering in 52 crops in 92 countries. Commelina diffusa, on the other hand, for being tolerant to the herbicide glyphosate, has become a major problem with the advent of the transgenic technology Roundup Ready (RR) in different crops (Opeña et al., 2014). Cynodon dactylon, according to Johnson and Davis (2012), causes significant economic damage in organic plantations due to its high capacity to reproduce by rhizomes, stolons, and seeds, combined with the absence of efficient control compatible with organic production standards.

Several studies demonstrate that weeds have greater development than agronomic crops in environments with limited resources (Berger et al., 2010; Opeña et al., 2014; Swanton et al., 2015). This occurs because, along with the genetic improvement of cultivated plants, the yield and quality of fruits were valued to the detriment of rusticity and edaphoclimatic adaptation (Bai et al., 2018). On the other hand, most spontaneous plants evolved through natural selection, developing several resistance mechanisms to adverse conditions in the environment, especially to water deficit in soil.

Water is vital for several physiological processes in plants, such as respiration, photosynthesis, cell division, absorption, and transport of nutrients, among others (Berger et al., 2010). However, the dispute with other sectors for this resource has increased every day due to climate changes combined with poor management of its 
use. According to data from the United Nations (ONU, 2015), if there are no improvements in water resource management by 2030, the planet could face a water deficit of $40 \%$, limiting agricultural production in a large portion of the world.

To increase the efficiency in water use by crops, an important measure adopted is the control of weeds because they remove, through evapotranspiration, a considerable volume of water from the soil (Farooq et al., 2019). However, weed management has distanced itself from the idea of total control. The reasons for this are the economic management of the plantation (comparison between the damage caused and the cost of control) and the attempt to reduce the selection pressure of plants that are resistant to several herbicide molecules (Beltran et al., 2012).

In Brazil, in plantations of fruit crops such as mango, citrus, and coffee, weeds grow in the interrow and are mainly controlled by the mechanical method (mechanical mowing). However, the loss of water through the evapotranspiration of weed species is not well understood, especially in tropical regions. There is a predominantly high soil temperature and moisture content in these regions, favoring the development of weeds and competition with crops.

In this context, it becomes necessary to understand better the interaction between soil, water, and weeds, which require data of various parameters, such as weed evapotranspiration $\left(\mathrm{ET}_{\mathrm{W}}\right)$, crop coefficient $(\mathrm{Kc})$, soil volume that these plants can explore, and the biomass produced over a given period. Concerning $\mathrm{ET}_{\mathrm{w}}$, there are several ways to estimate it, but the lysimeter method is the most accurate and direct, provided that the instrument is correctly installed (Bernardo et al., 2019).

A current option for Kc estimation is through a vegetation index. As Kc values' attribution is directly related to vegetative vigor, studies suggest that vegetation indices' temporal profiles can be used (Alface et al., 2019). Among the vegetation indices, the Normalized Difference Vegetation Index (NDVI) is the most used due to its sensitivity to the presence of pigments that participate in photosynthetic processes (Alam et al., 2018; Xue et al., 2017), as well as its easy application, enabling rapid and efficient detection of variations in vegetation (Alface et al., 2019). The objective of this study was to determine the water use and technical indices of different weed species.

\section{Material and Methods}

\subsection{Experimental area}

The experiment was carried out in the Experimental Area of Irrigation and Drainage of the Department of Agricultural Engineering of the Federal University of Viçosa (UFV), located in the municipality of Viçosa, MG, Brazil, inserted in the geographic region of Zona da Mata Mineira. The experiment was carried out from December 2018 to April 2019. According to Köppen's classification, the climate of the area is $\mathrm{C}$ wa. The average annual temperature is $20.1^{\circ} \mathrm{C}$, with yearly precipitation and reference evapotranspiration (ETo) of 1,289 $\mathrm{mm}$ and 1,229 $\mathrm{mm}$, respectively, according to the climate normal between 1981 and 2010 (INMET, 2018). The plant species used in this study were Commelina diffusa, Cyperus rotundus, Cynodon dactylon, and Paspalum notatum.

\subsection{Cultivation system}

The experiment was installed in drainage lysimeters to obtain the water consumption of the different weed species. Lysimeters are structures that enable direct and accurate determination of crop evapotranspiration (Bernardo et al., 2019). In the experiment, sixteen lysimeters were filled with Latossolo Vermelho Amarelo Distrófico (Oxisol) with the following physical and chemical characteristics (Table 1).

Although the soil fertility, depending on the crop, can be classified as low to medium, acidity correction and planting fertilization were not performed. This procedure was adopted due to the high capacity for nutrient absorption compared to commercial crops, as Fialho et al. (2012) pointed out.

The drainage lysimeters had the following dimensions: width of $1.10 \mathrm{~m}$, length of $1.53 \mathrm{~m}$, and depth of $0.70 \mathrm{~m}$, with $1.68 \mathrm{~m}^{2}$ of exposure area and soil volume equal to 1.01 $\mathrm{m}^{3}$ (Figure 1). The lysimeters were filled with a 5-cm-thick layer of crushed stone $\mathrm{n}^{\circ} 0$, a $10-\mathrm{cm}$-thick layer of sand, and a 50-cm-thick layer of soil. The soil surface inside and outside the lysimeters was left $5 \mathrm{~cm}$ below the lysimeter wall's edge to prevent water from entering and exiting by surface runoff during intense precipitation events. The design was in randomized blocks with four treatments and four replicates, considering each lysimeter as a plot. The arrangement of treatments in the experimental area is presented in Figure 1.

\begin{tabular}{|c|c|c|c|c|c|c|c|c|}
\hline $\mathrm{pH}$ & $P$ & K & $\mathbf{S}$ & B & $\mathrm{Cu}$ & Mn & $\mathrm{Fe}$ & Zn \\
\hline$-\mathrm{H}_{2} \mathrm{O}$ & \multicolumn{8}{|c|}{$\mathrm{mg} \mathrm{dm}^{-3} \ldots \ldots \ldots \ldots \ldots \ldots \ldots \ldots \ldots \ldots \ldots \ldots$} \\
\hline 4.21 & 1.6 & 69 & 0.1 & 0.06 & 3.6 & 21.2 & 49.8 & 0.93 \\
\hline
\end{tabular}

\begin{tabular}{|c|c|c|c|c|c|c|c|c|c|}
\hline OM & $\mathrm{Ca}^{2+}$ & $\mathrm{Mg}^{2+}$ & $\mathrm{Al}^{3+}$ & $\mathrm{H}+\mathrm{Al}$ & SB & $t$ & $T$ & V & P-rem \\
\hline \multicolumn{2}{|c|}{ dag $\mathrm{kg}^{-1}$} & & w & $\cdots . . . \mathrm{cmol}_{\mathrm{c}}$ & $\mathrm{dm}^{-3}$ & 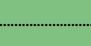 & a & & $\mathrm{mg} \mathrm{L}^{-1}$ \\
\hline 2.06 & 0.99 & 0.34 & 0 & 3.4 & 1.51 & 1.51 & 4.91 & 30.8 & 17.2 \\
\hline \multicolumn{2}{|c|}{$\begin{array}{c}\text { Coarse } \\
\text { sand }\end{array}$} & ine sanc & & Silt & Clay & FC & & NP & BD \\
\hline \multicolumn{6}{|c|}{ \% } & \multicolumn{3}{|c|}{$\mathrm{cm} \mathrm{cm}^{-3} \ldots$} &. $.9 \mathrm{~cm}^{-3} \ldots$ \\
\hline 15.8 & & 14.1 & & 4.6 & 55.5 & 0.291 & & 236 & 0.990 \\
\hline
\end{tabular}

$\mathrm{P}, \mathrm{K}, \mathrm{Cu}, \mathrm{Mn}, \mathrm{Fe}, \mathrm{Zn}$ extracted with Mehlich I. $\mathrm{Ca}^{2+}, \mathrm{Mg}^{2+}, \mathrm{Al}^{3+}$ extracted with $1 \mathrm{~mol} \mathrm{~L}^{-1} \mathrm{KCl}$. $\mathrm{H}+\mathrm{Al}$ extracted with $0.5 \mathrm{~mol} \mathrm{~L}^{-1}$ calcium acetate. SB - the sum of exchangeable bases. $t$ and $\mathrm{T}$ - effective cation exchange capacity and cation exchange capacity at $\mathrm{pH} 7$, respectively. V- base saturation. Field capacity (FC) and wilting point (WP) were obtained from the soil water tension curve for tensions of 33 and $1,500 \mathrm{kPa}$, respectively. 


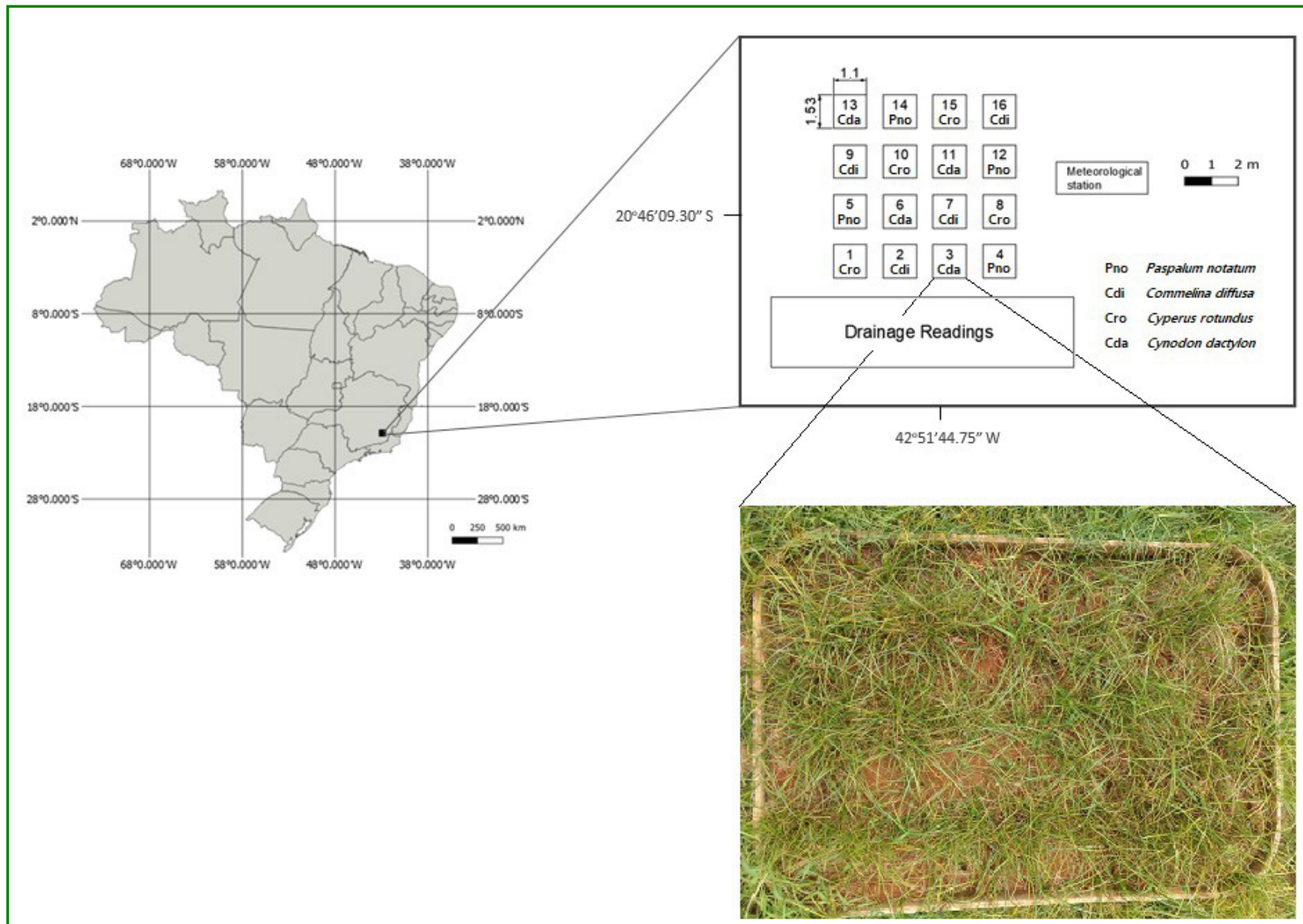

Figure 1 - Sketch of the experimental area with the imposed treatments. Viçosa-MG, DEA-UFV, 2018-2019.

The species Commelina diffusa and Cynodon dactylon were planted by vegetative propagation of the branches, whereas for Cyperus rotundus, it was decided to transplant young plants. For this, three furrows were opened within the lysimeters, $0.35 \mathrm{~m}$ apart and $0.20 \mathrm{~m}$ distant from the lysimeter edges. Concerning Paspalum notatum, there were already four lysimeters previously cultivated with this species. During the experimental period, any species of weeds other than those evaluated in the present study were manually removed. Around each lysimeter, the same weed species were planted to minimize the border effect.

\subsection{Lysimeter monitoring}

Initially, the lysimeters' soils were saturated to reach the moisture content corresponding to field capacity before transplantation. Drainage readings and irrigations were performed every 24 hours between 8:00 and 9:00 a.m. Drained and irrigated water volumes were measured with a graduated cylinder. Irrigations were performed to obtain a drained water volume of approximately 1.0 L. The entire drained volume was reapplied with the irrigation water, using a watering can (manually) in that same lysimeter to ensure the balance of salts and nutrients in the soil.
The water consumption equivalent to the weeds' evapotranspiration $\left(\mathrm{ET}_{\mathrm{W}}\right)$ was obtained through Equation 1 (García-Tejero et al., 2018).

$\mathrm{ETw}=1+\mathrm{P}-\mathrm{D}-\Delta \theta-\mathrm{R}$

where $\mathrm{ET}_{\mathrm{W}}$ is water consumption, $\mathrm{mm}$; I is the volume of irrigation water, $\mathrm{mm}$; $\mathrm{P}$ is the precipitation, $\mathrm{mm}$; $\mathrm{D}$ is the drainage, $\mathrm{mm} ; \Delta \theta$ is the variation of moisture in the soil between the beginning and end of the cycle; $\mathrm{R}$ is the runoff, assumed to be zero.

To transform the units into millimeters $(\mathrm{mm})$, the water volumes of irrigation and drainage were divided by the lysimeter area $\left(1.68 \mathrm{~m}^{2}\right)$. Regarding rainfall in the area, the rain gauge Paris Ville ( $400 \mathrm{~cm}^{2}$ area) was used to measure the volume of rainwater with the aid of a $500-\mathrm{mL}$ graduated cylinder.

The crop coefficient (Kc) was obtained by the ratio between weed evapotranspiration and reference evapotranspiration ( $\mathrm{ET}_{\mathrm{W}} / \mathrm{ETo}$ ) along the experimental period. The adopted ETo was obtained through the mean of the values of evapotranspiration of Paspalum notatum. For that, this grass was cultivated in lysimeters, with no limitations in terms of water and nutrients, and kept at the 
height of $12 \mathrm{~cm}$, as recommended by Allen et al. (1998). The obtained values of ETo were compared with the ETo estimated by the Penman-Monteith FAO-56 model (PMFAO56), described by Allen et al. (1998), considered by the Food and Agriculture Organization (FAO) as the standard equation due to its precision and accuracy (Equation 2).

ETo $=\frac{0.408 \Delta\left(R_{n}-\mathrm{G}\right)+\gamma \frac{900}{\mathrm{~T}+273} u_{2}\left(e_{s}-e_{a}\right)}{\Delta+\gamma\left(1+0.34 u_{2}\right)}$

where ETo is the reference evapotranspiration estimated by the PM-FAO56 equation, $\mathrm{mm} \mathrm{d}^{-1}$; $\Delta$ is the slope of the saturation vapor pressure curve, $\mathrm{kPa}^{\circ} \mathrm{C}^{-1} ; \mathrm{R}_{n}$ is net radiation on the surface, MJ m${ }^{-2} \mathrm{~d}^{-1} ; \mathrm{G}$ is the soil heat flux, MJ m $\mathrm{m}^{-2} \mathrm{~d}^{-1}$; $\mathrm{T}$ is the average air temperature, ${ }^{\circ} \mathrm{C} ; \mathrm{u}_{2}$ is the wind speed at $2 \mathrm{~m}$ height, $\mathrm{m} \mathrm{s}^{-1}$; $\mathrm{e}_{\mathrm{s}}$ is the saturation vapor pressure, $\mathrm{kPa} ; \mathrm{e}_{\mathrm{a}}$ is the partial vapor pressure, $\mathrm{kPa} ; \gamma$ is the psychrometric constant, $\mathrm{kPa}^{\circ} \mathrm{C}^{-1}$.

\subsection{Meteorological data}

Meteorological data were obtained from the automatic weather station (DAVIS, Vantage Pro model, USA) located close to the lysimeters. Daily data were collected along the experimental cycle and are presented in Figure 2.

Along the experimental cycle, the average values of air temperature, relative humidity, solar radiation, and wind speed were $23.1{ }^{\circ} \mathrm{C}, 79.4 \%, 20.1 \mathrm{MJ} \mathrm{m}^{-2} \mathrm{~d}^{-1}$, and $0.66 \mathrm{~m} \mathrm{~s}^{-1}$, respectively.

\subsection{Evaluated characteristics of weeds}

In the present study, the following characteristics of the different weed species were evaluated: evapotranspiration $(\mathrm{mm})$, biomass $\left(\mathrm{kg} \mathrm{m}^{-2}\right)$, shoot dry mass $\left(\mathrm{kg} \mathrm{m}^{-2}\right)$, root depth $(\mathrm{cm})$, water productivity $\left(\mathrm{kgm}^{-3}\right)$, and Normalized Difference Vegetation Index (NDVI).

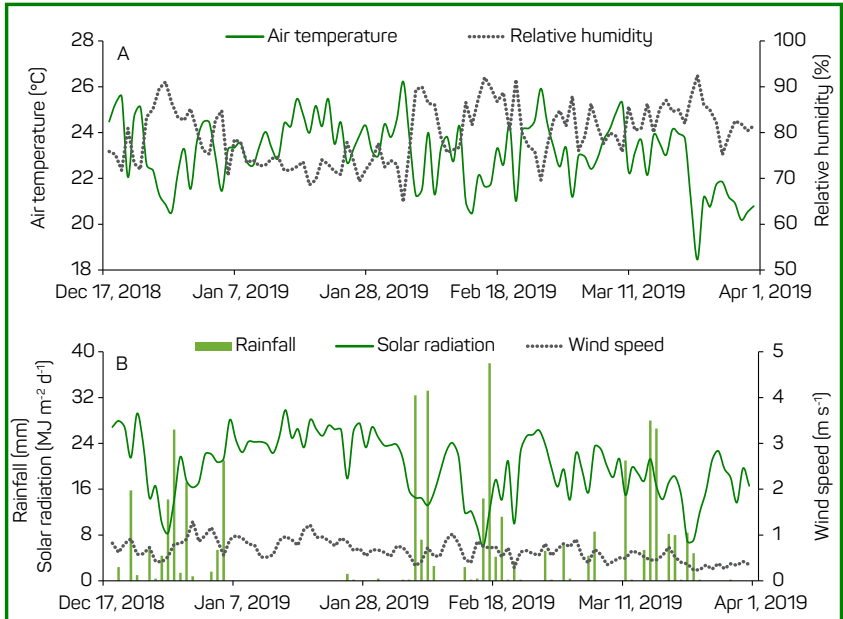

Figure 2 - Daily variation of (A) air temperature, relative air humidity, (B) solar radiation, wind speed at $2 \mathrm{~m}$ height, and rainfall along the experimental cycle. Viçosa-MG, DEA-UFV, 2018-2019.
At the end of the experiment, biomass was evaluated in two distinct ways, being estimated by non-destructive analyses (NDVI) and measured by destructive analysis. For the first analysis, the NDVI was measured by a portable, terrestrial remote sensor (GreenSeeker, Trimble, USA). In this device, NDVI values range from 0 to 1 , and values close to 1 are found in well-nourished and healthy plants. This is because vigorous plants absorb radiation more in the red range $(650 \mathrm{~nm})$ and reflect the near-infrared $(770 \mathrm{~nm})$, as demonstrated by Alface et al. (2019) in Equation 3.

NDVI $=\frac{p n i r-p r}{p n i r+p r}$

where NDVI is the normalized difference vegetation index; pnir is the reflectance in the near-infrared $(770 \mathrm{~nm}) ; p r$ is the reflectance in red $(650 \mathrm{~nm})$.

NDVI readings were performed on average every three days, with the device positioned at the center of the lysimeters and $0.6 \mathrm{~m}$ height from the plants, according to the recommendation of Zhitao et al. (2014). Thus, the readings were taken along the lysimeters' entire length, and the average of two readings per lysimeter was collected. It worth pointing out that RGB images were taken after the readings with Greenseeker ${ }^{\mathrm{Tm}}$ to compare them with the respective values of NDVI.

For biomass analysis by the destructive method, the weeds were cut at soil level to remove the shoots at the end of the study, and the material was weighed. The value found was divided by the exposure area $\left(1.68 \mathrm{~m}^{2}\right)$ to obtain the biomass in $\mathrm{kg} \mathrm{m}^{-2}$.

After weighing the biomass of each lysimeter, the replicates of the treatments were grouped and homogenized. Immediately after, two samples of $250 \mathrm{~g}$ were collected, placed in paper bags, and dried in an oven at around $60{ }^{\circ} \mathrm{C}$ for 72 hours. After the drying process, the samples were weighed, and the dry mass value obtained as a percentage was converted into $\mathrm{kg} \mathrm{m}^{-2}$.

To evaluate root depth $(\mathrm{cm})$, soil pits were opened in the lysimeters' central region, with the following dimensions: $0.3 \mathrm{~m}$ wide, $1.0 \mathrm{~m}$ long, $0.5 \mathrm{~m}$ deep. Then, the measurement was performed from the soil level to the depth where $80 \%$ of the root system was concentrated, using a metric ruler (Bernardo et al., 2019).

Water productivity was determined by Equation 4 .

$$
\mathrm{WP}=\frac{B i 0^{*} 1000}{\mathrm{ETw}}
$$

where WP is the water productivity, $\mathrm{kg} \mathrm{m}^{-3}$; Bio is the biomass of the weed, $\mathrm{kg} \mathrm{m}^{-2}$; ETw is the accumulated evapotranspiration of the lysimeter, $\mathrm{mm}$.

\subsection{Statistical analysis}

The results were subjected to analysis of variance by $\mathrm{F}$ test at 0.05 probability level. Subsequently, the means were compared by Tukey test at 0.05 probability level. Paired t-test was used for the NDVI data. The statistical 
analyses were performed using the statistical program $R$ ( $R$ Development Core Team, 2017).

\section{Results and Discussion}

\subsection{Plant characteristics}

The evaluated characteristics of weeds and the accumulated evapotranspiration of $P$. notatum are presented in Table 2. C. diffusa showed higher accumulated evapotranspiration, root depth, biomass, and water productivity than the other species. This species was also the one with the highest growth and water consumption. Its water consumption $(473.3 \mathrm{~mm})$ is comparable to that of an agronomic crop, such as corn (468 to $476 \mathrm{~mm}$ ) (Niaghi et al., 2019). On the other hand, C. rotundus, in general, showed low growth of deep roots, biomass, and water productivity.

According to Fan et al. (2016), at least half of the root biomass of 14 crops of great relevance in the world can be found within the first $20 \mathrm{~cm}$ of soil. Therefore, it is clear that the studied weeds compete for water and nutrients in the same soil layer explored by most crops. Regarding biomass, the yield of $C$. diffusa was three times higher than that of C. dactylon, but there was no significant difference between the two weeds in terms of dry shoot weight. This is due to the high relative amount of water in C. diffusa $(85.45 \%)$ compared to C. dactylon (60.50\%).

\subsection{Water consumption}

The accumulated water consumption, obtained through the evapotranspiration, of the three weeds, of P. notatum, and the reference evapotranspiration (ETo by PM-FAO56) along the experimental period are presented in Figure 3. Total water consumption was equal to $473.3,344.6$, and $335.8 \mathrm{~mm}$ for $C$. diffusa, C. rotundus, and C. dactylon, respectively. For $P$. notatum, the total water consumption was $412.6 \mathrm{~mm}$, slightly lower than the ETo estimated by PM-FAO56. C. diffusa had the highest evapotranspiration compared to the other weeds. C. dactylon, and C. rotundus

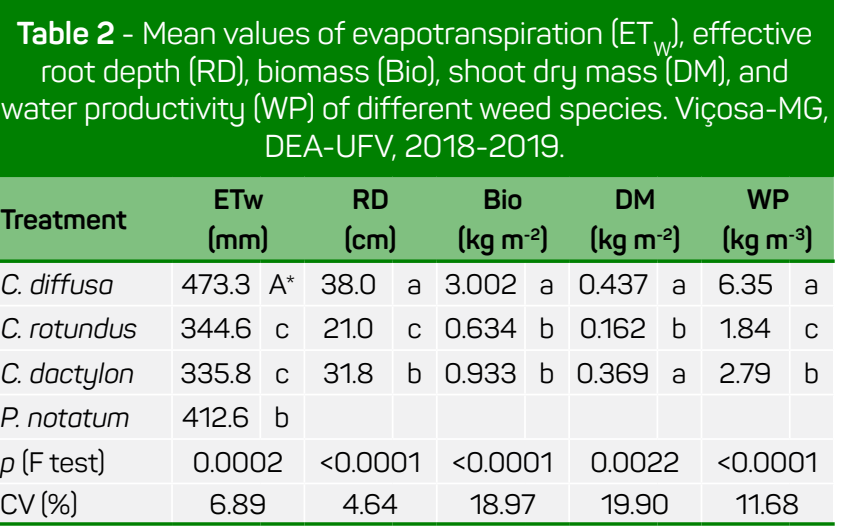

*Means followed by the same letter in the column do not differ by Tukey test $(p<0.05)$ showed similar water consumption. The growth of $C$. diffusa after planting was higher than those of the other weeds and, from the beginning of February, it covered the entire soil of the lysimeter. Probably, this biomass formed positively influenced the increase in the transpiration component, hence increasing evapotranspiration.

The estimate of ETo by the PM-FAO56 model was very similar to the ETo measured by the lysimeter with $P$. notatum. Correct management of the lysimeter guarantees reliable values of ETo (Bernardo et al., 2019). Therefore, this model can be used to quantify the ETo locally; however, that model requires many meteorological variables that are often not available under field conditions.

\section{3 $\mathrm{ET}_{\mathrm{w}} / \mathrm{ETo}$ ratio (crop coefficient)}

The ratios between weed evapotranspiration and reference evapotranspiration ( $\mathrm{ET}_{\mathrm{W}} / \mathrm{ETo}$ ) for the three weeds and P. notatum are presented in Figure 4. This ratio between $\mathrm{ET}_{\mathrm{W}} / \mathrm{ETo}$ can also be referred to as crop coefficient $(\mathrm{Kc})$. The fitted models were logarithmic for the three weeds and linear for P. notatum. In general, the variance explained by the models was reasonable, with coefficients of determination $\left(R^{2}\right)$ between $30.92 \%$ and $54.61 \%$. Moreover, although the cluster of points has a greater dispersion from the middle of the experimental cycle, the models' coefficients were significant, demonstrating that the Kc found can determine the volume of water lost in an agricultural system to the consumption of the studied weeds.

Several factors influence Kc, such as type of crop, development stage, soil characteristics, and local climatic conditions (Allen et al., 1998; Bernardo et al., 2019; SegoviaCardoso et al., 2019). According to Allen et al. (1998), $\mathrm{Kc}$ undergoes extreme variation according to the crop's phenological stage. Still, climatic factors that promote greater transpiration of plants, such as strong winds and low relative humidity, generate daily Kc variations, as shown in Figure 4.

Until 45 days after transplantation, all treatments except $P$. notatum had a logarithmic increase in the $\mathrm{ET}_{\mathrm{W}} / \mathrm{ETo}$ ratio. The factor that explains such fast growth is the increase in leaf area index (ratio between leaf area and the terrain surface area) and, consequently, higher

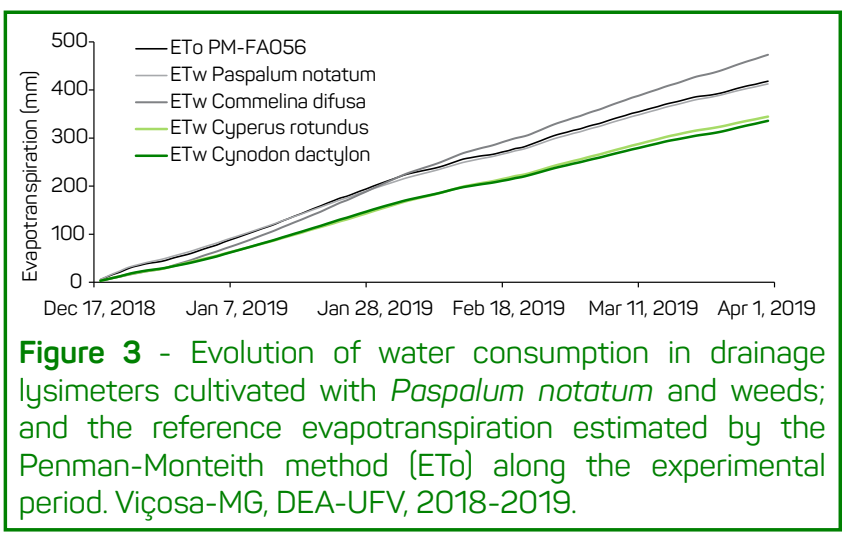


photosynthetic rate, which favors weed evapotranspiration (Alam et al., 2018). After this initial development stage, the weeds covered the lysimeters' entire soil, initiating a stable relationship between biomass production and senescence of old leaves, stabilizing their Kc at a high value.

In the final third of the experimental cycle, Kc's mean values for $C$. diffusa, $C$. rotundus, and $C$. dactylon were 1.32 ,

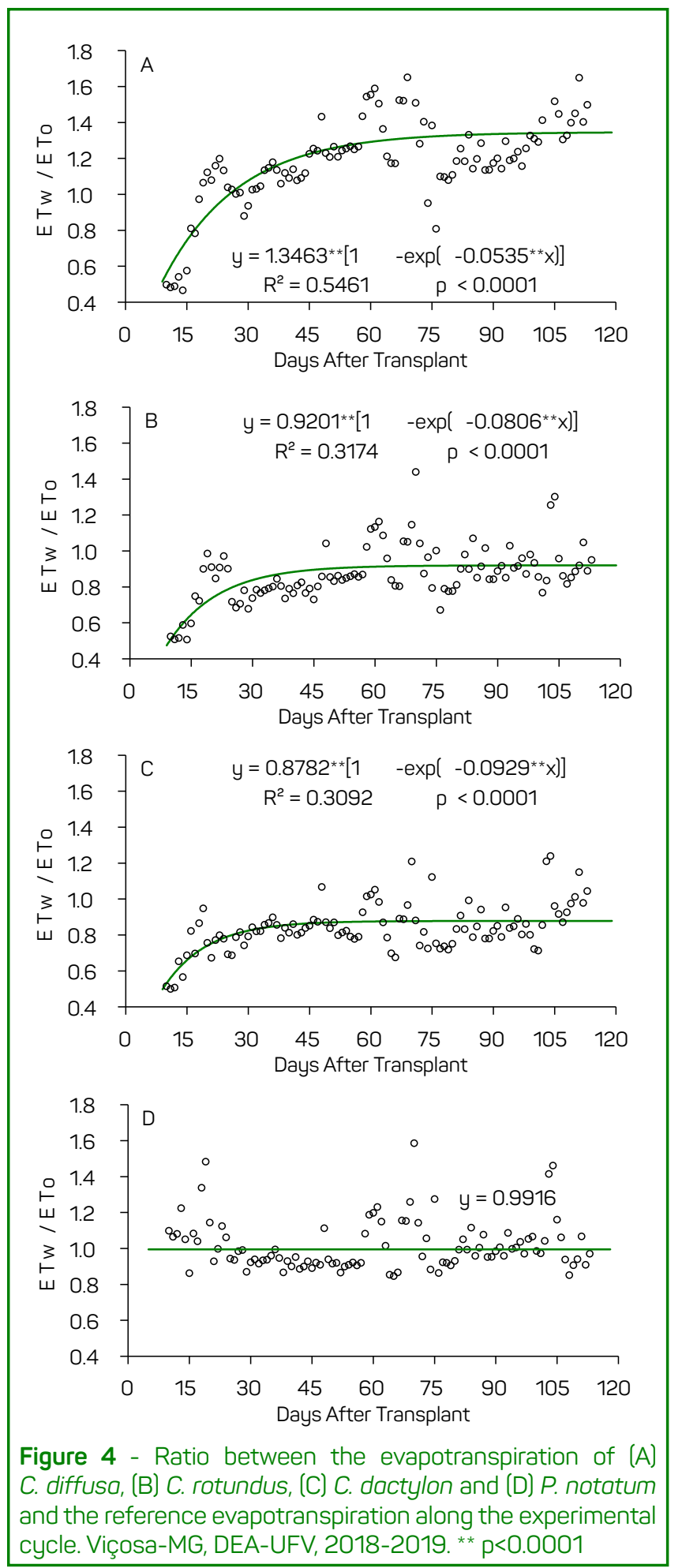

0.93, and 0.90, respectively. It can be noted that the Kc value for $C$. diffusa is higher than the Kc found in the phase of highest water demand of many crops, such as corn (1.20), soybean (1.27), coffee (1.10), and citrus (0.85); for coffee and citrus, this Kc value is already for crops with the presence of weeds (Allen et al., 1998; Segovia-Cardoso et al., 2019; Silva et al., 2019). In the lysimeters cultivated with $P$. notatum, as expected, the ratio between $\mathrm{ET}_{\mathrm{W}}$ and the ETo estimated by the Penman-Monteith model remained almost equal to the unit (0.9916) throughout the experimental cycle.

The critical period for prevention of weed interference (CPPI), that is, the time when the crop should be kept free of invasive plants, for banana is 30 days after planting (Carvalho and Vargas, 2008), and for recently planted coffee is 22 to 38 days after planting the seedlings (Dias et al., 2005). However, if the establishment of the weeds coincides with that of the crop, before the start of the CPPI, the water consumption of the weeds will already be high (Figure 4). This can result in damage to the crop, as well as an increase in the amount of water to be applied by irrigation. Extra irrigation will be needed to compensate for weeds' water consumption.

These results show that weeds' water consumption cannot be neglected, mainly when they occur simultaneously to agronomic crops, mostly perennial crops with irrigation in total area.

\subsection{Estimation of $\mathrm{ET}_{\mathrm{w}} / \mathrm{ETo}$ ratio by NDVI}

The Normalized Difference Vegetation Index (NDVI) showed a linear and positive relationship with the Kc of the three weeds and P. notatum (Figure 5). In general, the variance explained by the models was reasonable, with $\mathrm{R}^{2}$ ranging from $32.6 \%$ to $60.1 \%$, and the coefficients of all treatments were significant, demonstrating the accuracy of the method in defining the Kc based on the NDVI. According to Alface et al. (2019), the quick and accurate estimate of Kc can be performed through measurements of NDVI.

It is verified that the $\mathrm{R}^{2}$ values found in this study are lower than those found for different crops (Alface et al., 2019; Mahmoud and Gan, 2019; Oliveira et al., 2020). In these studies, some crops, such as sugar cane, wheat, potato, sorghum, zucchini, etc., were evaluated and, in all of them, $\mathrm{R}^{2}$ was above $70 \%$. A possible explanation for these low values of $\mathrm{R}^{2}$ would be that the weeds were transplanted, and from the beginning, there was already part of the soil covered by them. Also, weeds were able to cover a large percentage of the soil quickly, increasing NDVI. Therefore, our minimum NDVI values, possibly, were higher than those found in other studies, and we had a smaller amount of these minimum values. After stabilizing the land cover, the NDVI values also showed lower oscillations, unlike the studies mentioned, where there was less vegetative vigor in crops and the consequent reduction of NDVI in 
the fourth stage of development. These facts combined make our NDVI values closer to the average value, where the model is unable to capture these changes and the correlation is reduced. Also, in our results, we noticed that P. notatum had the lowest $\mathrm{R}^{2}$ because, in this treatment, there was less variation in NDVI as the crop was already established at the beginning of the experimental period and covered a large part of the soil because we needed it to obtain the reference evapotranspiration (ETo).
In the present study, the portable terrestrial remote sensor (GreenSeeker, Trimble, USA) used to measure NDVI proved to be a potential alternative to estimate Kc along the cycles of the weeds and P. notatum. There are also other ways to obtain this index, such as by orbital remote sensing. Segovia-Cardozo et al. (2019), for instance, estimated the Kc of corn through the NDVI obtained with images from the Landsat 8 and Sentinel 2A and 2B satellites, available free of charge. It should be pointed

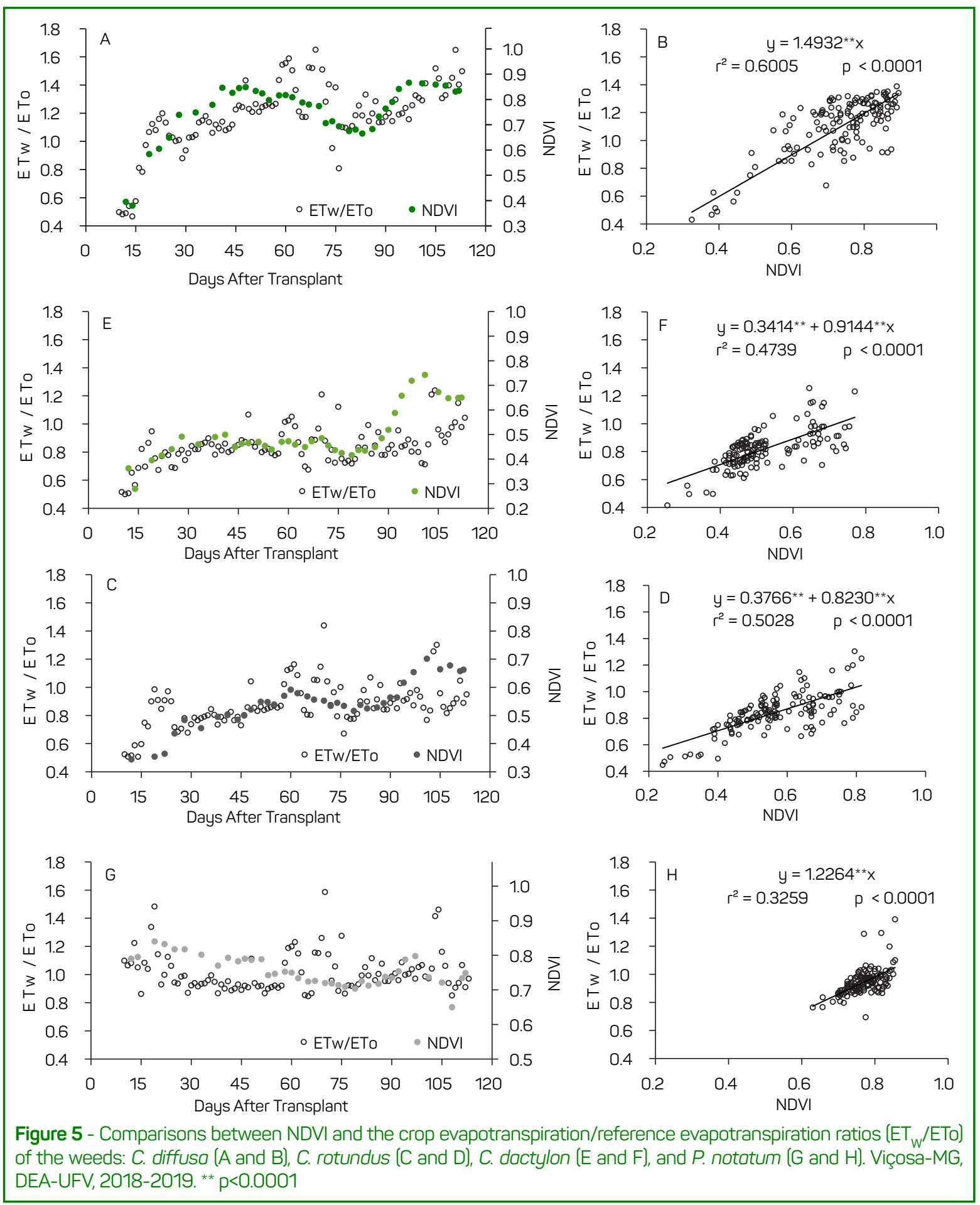


out that the above-mentioned authors found Kc values very similar to the actual coefficients recommended by the Irrigation Consulting Service for Castilla and León (ITACyL). In another study conducted by Alam et al. (2018), pastures were sampled two and three weeks after cutting, showing a positive linear relationship between Kc and NDVI.

Along the study, for visual monitoring of the variation in the vigor of weeds and $P$. notatum, against the value of NDVI, RGB images were obtained for all treatments. In Figure 6, it is possible to note a relationship between NDVI and the soil cover by the canopy of the weeds, represented by leaf area index (LAI), which is consistent with several studies (Liu et al., 2018; Rahman and Lamb, 2016). However, some factors may affect LAI's estimation through NDVI, such as incorrect classification of crops and saturation of reflectance in the infrared range, for cases of dense canopies (Riihimäki et al., 2017; Xue et al., 2017). Regarding the low NDVI values of $C$. rotundus and $C$. dactylon, the explanation is the morphology of these species, which have low vegetative vigor compared to the others.

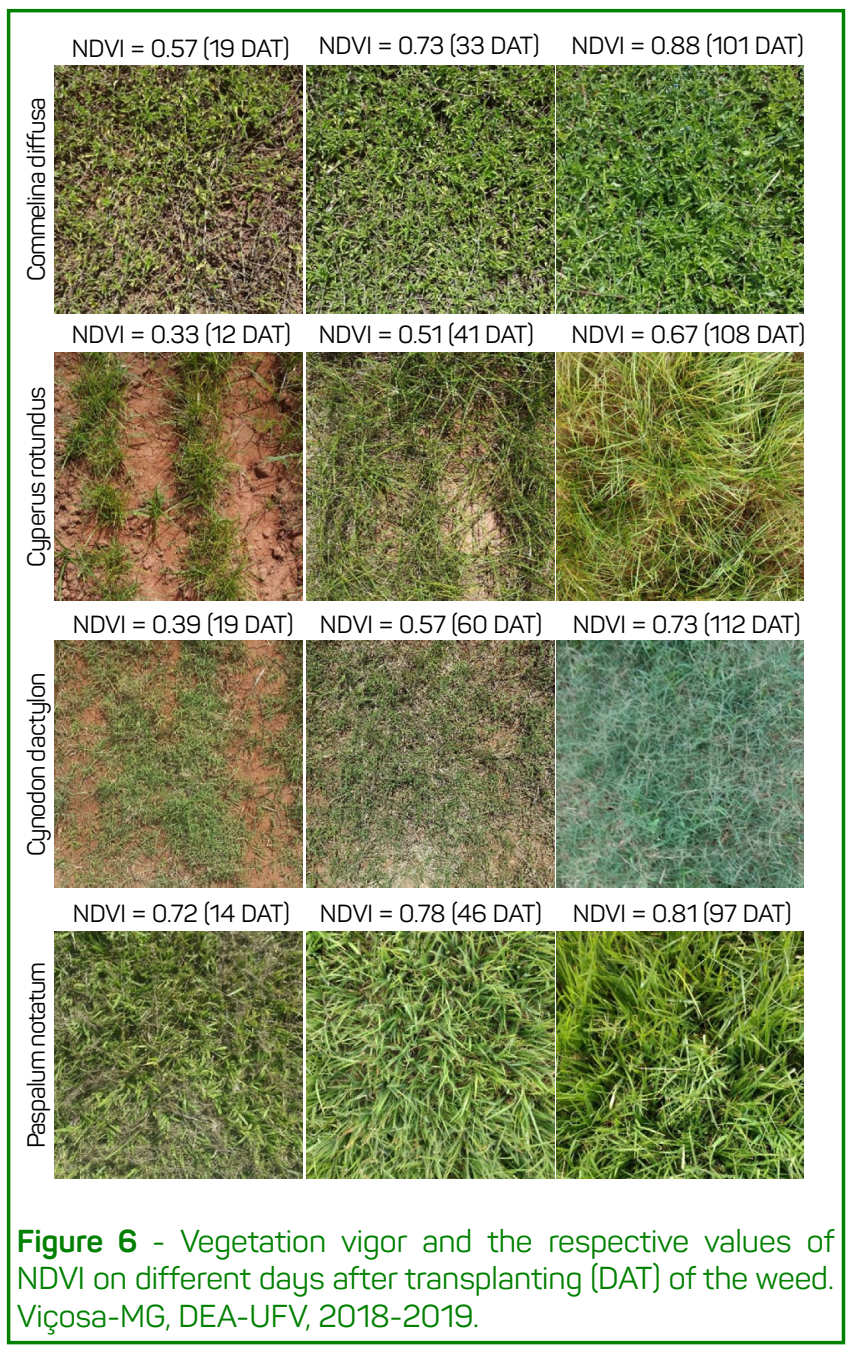

\subsection{Estimation of biomass by NDVI}

The linear ratio of weed biomass as a function of NDVI is presented in Figure 7. The biomass values expressed in the graph come from the destructive analysis performed in each replicate, while the NDVI comes from the reading taken hours before harvest. Regarding the variance explained by the models, the results were satisfactory, with $\mathrm{R}^{2}$ equal to $63.1 \%$, $46.1 \%$, and $59.7 \%$ for C. diffusa, C. rotundus, and C. dactylon, respectively. Therefore, NDVI can also be an adequate alternative to estimate biomass. According to Xue et al. (2017), the NDVI has a strong linear relationship with biomass, accounting for $66 \%$ of green biomass variability above the soil in all sampling sites. However, Riihimäki et al. (2017) found an exponential relationship between biomass and NDVI when studying the distribution of biomass in northwestern Finland's tundras.
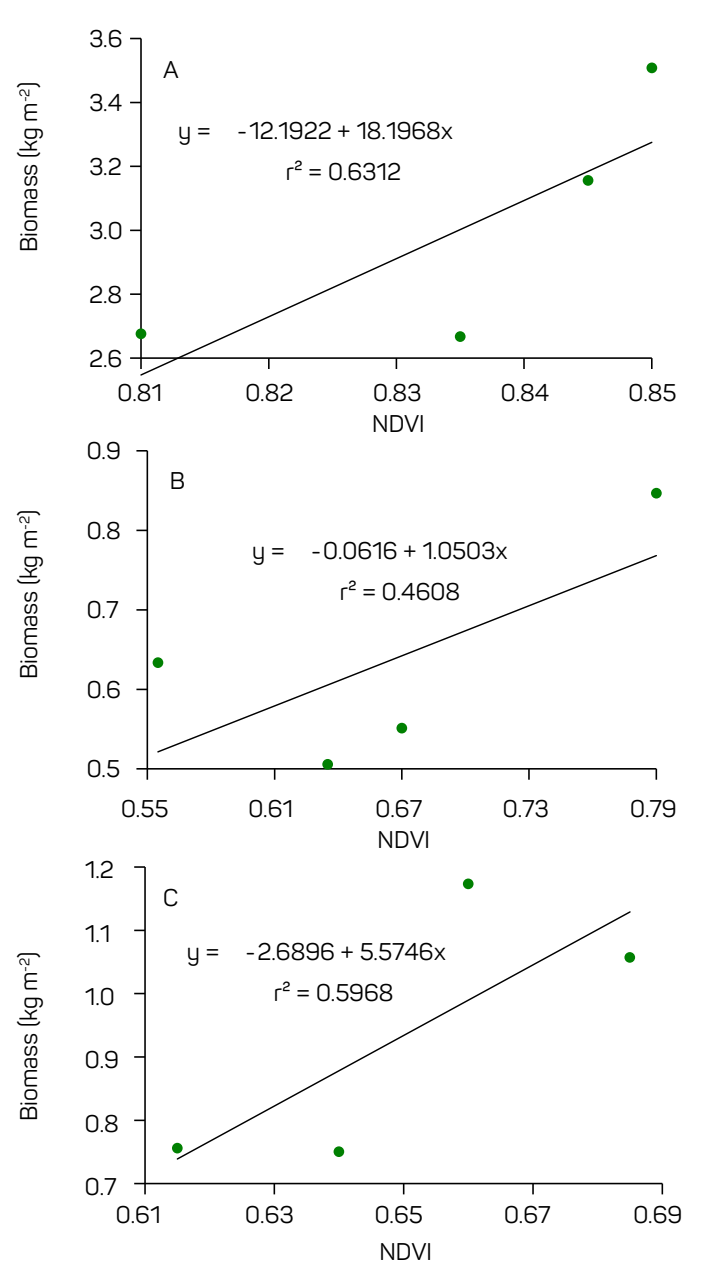

Figure 7 - Estimation of biomass for $C$. diffuso (A), C. rotundus (B) and C. dactylon (C) as a function of NDVI. Viçosa-MG, DEA-UFV, 2018-2019 


\section{Conclusions}

Total water consumption was equal to 473.3, 344.6, and $335.8 \mathrm{~mm}$ for $C$. diffusa, C. rotundus, and $C$. dactylon, respectively.

The highest values of crop coefficient were recorded during the final third of the experimental cycle, being equal to 1.32 (C. diffusa), 0.93 (C. rotundus), and 0.90 (C. dactylon).

NDVI can be used in the estimation of the crop coefficient and biomass of weeds.

The results found in the present study can serve as the basis for future research and assist farmers and technicians in weed management and in improving water use efficiency.

\section{Author's contributions}

All authors: conceptualization, data curation, formal analysis, methodology, writing - original draft preparation. FFC: funding acquisition, project administration, supervision. TFR, GHS, and SBC: investigation. FFC, and GHS: Resources. TFR, FFC, and GHS: visualization. TFR, and FFC: writing review \& editing.

\section{Financing}

The authors thanks to the financial support provided by Conselho Nacional de Desenvolvimento Científico e Tecnológico - CNPq (Project code 434484/2018-0) and Coordenação de Aperfeiçoamento de Pessoal de Nivel Superior - Capes (Finance code 001).

\section{References}

Alam MS, Lamb DW, Rahman MM. A refined method for rapidly determining the relationship between canopy NDVI and the pasture evapotranspiration coefficient. Comput Electron Agric. 2018;147:12-7. Available from: https://doi.org/10.1016/j.compag.2018.02.008

Alface AB, Pereira SB, Filgueiras R, Cunha FF. Sugarcane spatial-temporal monitoring and crop coefficient estimation through NDVI. Rev Bras Eng Agric Ambient. 2019;23(5):330-5. Available from: https://doi.org/10.1590/1807-1929/agriambi.v23n5p330-335

Allen RG, Pereira LS, Raes D, Smith M. Crop evapotranspiration: guidelines for computing crop water requirements. Rome: FAO; 1998.

Bai S, Yu H, Wang B, Li J. Retrospective and perspective of rice breeding in China. J Genet Genomics. 2018;45(11):603-12. Available from: https://doi.org/10.1016/j.jgg.2018.10.002

Beltran JC, Pannell DJ, Doole GJ, White B. A bioeconomic model for analysis of integrated weed management strategies for annual barnyardgrass (Echinochloo crus-galli complex) in Philippine rice farming systems. Agric Syst. 2012;112:1-10. Available from: https://doi.org/10.1016/j.agsy.2012.06.003

Berger A, Mcdonald A, Riha S. A coupled view of above and below-ground resource capture explains different weed impacts on soil water depletion and crop water productivity in maize. Field Crops Res. 2010;119(23):314-21. Available from: https://doi.org/10.1016/j.fcr.2010.07.023

Bernardo S et al. [Irrigation manual]. Viçosa: Editora UFV; 2019. Portuguese.

Carvalho JE, Vargas L. [Management and control of weed plants in fruit trees]. In: Vargas L, Roman ES, editors. [Weed management and control manual]. Passo Fundo: Embrapa Trigo, 2008. p. 561-601. Portuguese.

Cirujeda A, Anzalone A, Aibar J, Moreno MM, Zaragoza C. Purple nutsedge (Cyperus rotundus L.) control with paper mulch in processing tomato. Crop Prot. 2012;39:66-71. Available from: https://doi.org/10.1016/j.cropro.2012.03.028

Das TK. Basics and applications. New Delhi: Weed Science; 2008.

Dias TD, Alves PD, Lemes LN. [Interference periods of Commelina benghalensis after coffee establishment]. Plan- ta Daninha. 2005;23(3):397-404. Portuguese. Available from: https://doi.org/10.1590/S0100-83582005000300002

Fan J, Mcconkey B, Wang $\mathrm{H}$, Janzen $\mathrm{H}$. Root distribution by depth for temperate agricultural crops. Field Crops Res. 2016;189:68-74. Available from: https://doi.org/10.1016/j.fcr.2016.02.013

Farooq M, Hussain M, Ul-Allah S, Siddique KH. Physiological and agronomic approaches for improving water-use efficiency in crop plants. Agric Water Manage. 2019;219:95-108. Available from: https://doi.org/10.1016/j.agwat.2019.04.010

Fialho CM, Silva AA, Faria AT, Torres LG, Rocha PR, Santos JB. [Phyto-sociological assessment of pasture]. Planta Daninha. 2012;30(1):65-73. Portuguese. Available from: https://doi.org/10.1590/S0100-83582012000100008

García-Tejero IF, López-Borrallo D, Miranda L, Medina JJ, Arriaga J, Muriel-Fernández JL, et al. Estimating strawberry crop coefficients under plastic tunnels in Southern Spain by using drainage lysimeters. Sci Hortic. 2018;231:233-40. Available from: https://doi.org/10.1016/j.scienta.2017.12.020

Instituto Nacional de Meteorologia - INMET. [Normal climate of Brazil 1981-2010]. 2018 [cited 2020 Jan 3]. Portuguese. Available from: http:// www.inmet.gov.br/portal/index.php?r=clima/normaisClimatologicas

Johnson WC 3rd, Davis JW. Techniques for Cynodon doctylon (L.) Pers. control suitable for use in fallow organic transition in the southeastern U.S. coastal plain. Crop Prot. 2012;39:63-5. Available from: https://doi.org/10.1016/j.cropro.2012.04.007

Liu L, Yang X, Zhou H, Liu S, Zhou L, LiX, etal. Evaluating the utility of solar-induced chlorophyll fluorescence for drought monitoring by comparison with NDVI derived from wheat canopy. Sci Total Environ. 2018;625:120817. Available from: https://doi.org/10.1016/j.scitotenv.2017.12.268

Mahmoud SH, Gan TY. Irrigation water management in arid regions of Middle East: assessing spatio-temporal variation of actual evapotranspiration through remote sensing techniques and meteorological data. Agric Water Manage. 2019;212:35-47. Available from: https://doi.org/10.1016/j.agwat.2018.08.040 
Niaghi AR, Jia X, Steele DD, Scherer TF. Drainage water management effects on energy flux partitioning, evapotranspiration, and crop coefficients of corn. Agric Water Manage. 2019;225:105760. Available from: https://doi.org/10.1016/j.agwat.2019.105760

Oliveira RM, Cunha FF, Silva GH, Andrade LM, Morais CV, Ferreira PM, et al. Evapotranspiration and crop coefficients of Italian zucchini cultivated with recycled paper as mulch. PLoS One. 2020;15(5):e0232554. Available from: https://doi.org/10.1371/journal.pone.0232554

Opeña JL, Quilty JR, Correa TQ Jr, Chauhan BS. Weed population dynamics, herbicide efficacies, and crop performance in a sprinkler-irrigated maize-rice cropping system. Field Crops Res. 2014;167:119-30. Available from: https://doi.org/10.1016/j.fcr.2014.07.014

Organização das Nações Unidas - ONU. UN Report: World Faces 40\% Water Shortfall by 2030. 2015 [cited 2020 Jan 3]. Available from: https://www.un.org/press/en/

R Development Core Team. R: A language and environment for statistical computing. Vienna: R Foundation for Statistical Computing; 2017 [cited 2019 Dec 15]. Available from: http://www.R-project.org/

Rahman MM, Lamb DW. Trigonometric correction factors renders the fAPAR-NDVI relationship from active optical reflectance sensors insensitive to solar elevation angle. Comput Electron Agric. 2016;121:437. Available from: https://doi.org/10.1016/j.compag.2015.11.020

Riihimäki $H$, Heiskanen J, Luoto $M$. The effect of topography on arctic-alpine aboveground biomass and NDVI patterns. Int J Appl Earth Obs Geoinf. 2017;56:44-53. Available from: https://doi.org/10.1016/j.jag.2016.11.005
Rockenbach AP, Rizzardi MA, Nunes AL, Bianchi MA, Caverzan A, Schneider T. [Interference between weeds and crop: changes in secondary metabolism]. Rev Bras Herbic. 2018;17(1):59-70. Portuguese. Available from: https://doi.org/10.7824/rbh.v17i1.527

Segovia-Cardozo DA, Rodríguez-Sinobas L, Zubelzu S. Water use efficiency of corn among the irrigation districts across the Duero river basin (Spain): estimation of local crop coefficients by satellite images. Agric Water Manage. 2019;212:241-51. https://doi.org/10.1016/j.agwat.2018.08.042

Silva EHFM, Gonçalves AO, Pereira RA, Fattori IM Jr, Sobenko LR, Marin FR. Soybean irrigation requirements and canopy-atmosphere coupling in Southern Brazil. Agric Water Manage. 2019;218:1-7. Available from: https://doi.org/10.1016/j.agwat.2019.03.003

Swanton CJ, Nkoa R, Blackshaw RE. Experimental methods for cropweed competition studies. Weed Sci. 2015;63(SP1):2-11. Available from: https://doi.org/10.1614/WS-D-13-00062.1

Xue J, Ge Y, Ren H. Spatial upscaling of green aboveground biomass derived from Modis-based NDVI in arid and semiarid grasslands. Adv Space Res. 2017;60(9):2001-8. Available from: https://doi.org/10.1016/j.asr.2017.07.016

Zhitao Z, Lan Y, Pute W, Wenting $\mathrm{H}$. Model of soybean NDVI change based on time series. Int J Agric Biol Eng. 2014;7(5):64-70. Available from: https://doi.org/10.3965/j.jijabe.20140705.007 